\title{
Histories of the Self: Anne-Lois Girodet and the Trioson Portrait Series
}

\section{Stephanie O'Rourke}

In 1804 the French painter Anne-Louis Girodet drew a small post-mortem portrait of Benoît-Agnès Trioson, the sole biological child of the artist's mentor, Benoît-François Trioson (fig. 1). The boy's wavy hair is rendered in fluid, decisive streaks of charcoal, but his facial features - the contours of his jaw, lips, nose, and eye - are much harder to make out. The boy seems to fade from view, as if the artist had moved quickly to record his features one last time before they slipped away altogether. The drawing serves as a postscript, of sorts, to a trio of painted portraits Girodet executed of the young Benoît-Agnès in 1797 (fig. 2), 1800 (fig. 3), and 1803 (fig. 4), a portrait series that was abruptly brought to a close with the child's untimely death in 1804. Both in their serial treatment of a young child and in their precarious placement between the final throes of the French Revolution and the rise of Napoleon's First Empire, the paintings are rare documents of the affective terrain of boyhood at the end of the eighteenth century. Girodet paid exceptionally close attention to the physical and psychic particularities of youth and in doing so reflected, it has been argued, a dreamy, rebellious, and melancholic vision of childhood memorably articulated in Jean-Jacques Rousseau's Emile of 1762. This notion of childhood was similarly bound up in evolving philosophical, social, and political changes underway within the bourgeois model of the nuclear family. ${ }^{i i}$ But childhood was not merely a topic of interest for its own stake; it was a concept freighted with the competing claims about equality, freedom, and morality that had urgent political stakes at the twilight of the eighteenth century. 
In their modest size and psychic intimacy, the Trioson portraits seem like a pointed divergence from the large-scale history paintings for which Girodet is best known, which often feature dramatically-rendered heroic nudes and theatrical luminous effects. Instead, the portraits were a particularly personal undertaking for the artist. The child's father, Benoît-François, was a distinguished medical doctor who had overseen Girodet's education from his youth and had nurtured his earliest ambitions to become an artist. The subtle, penetrating likenesses Girodet produced of the doctor's only biological child were evidence of his routine presence at the Trioson family home and his access to the young boy's private, unguarded moments. The paintings were "personal" in a different sense too, in that they addressed the boy's personhood, his developing identity. Yet they did so in a way that proved far more complex than conventional child portraiture: the serial manner in which Benoît-Agnès was painted placed particular emphasis on his identity as it was constructed over time, describing his selfhood as the result of an ongoing process rather than a fixed and immutable fact. Doing so framed selfhood as a historical phenomenon, as the effect of multiple durational temporalities. Despite their scale and subject matter, then, the Trioson portrait series was not as remote from history painting as it might initially appear. Their conceptual adjacency was underscored by Girodet himself when he insisted that the first portrait in the series ought to be classified as a "historical genre" painting, claiming for it historical depths as well as intellectual and artistic ambitions. ${ }^{\text {iii }}$

Scholars often approach portraiture from this particular moment with an eye to the political dimensions of identity as they were figured vis-à-vis the French Revolution. ${ }^{\text {iv }}$ Eighteenth-century child portraiture, although equally capable of engaging with politics, is more often framed in terms of changing affective, familial, and pedagogical structures. ${ }^{v}$ However, in taking seriously Girodet's claims for its "historicality," I propose that the Trioson portrait series 
does more than this: it explores history and selfhood as deeply imbricated phenomena. The series treats such categories as cumulative and varied in their pictorial, material, and philosophical operations. ${ }^{\text {vi }}$ In what follows, I sketch out a number of durational and sequential processes at work in the paintings - processes both active and dormant - in order to consider just a few of the many histories that are embedded in the portraits. Through engagement with such temporalities, the works grapple with what it means to be, or rather, to become a person around the turn of that century, a messy and durational process in which various kinds of histories collect around the moi, the "self." vii

\section{Series and Sequence}

Serial portraiture, a rare luxury among bourgeois patrons of the period, often focused on important moments in the sitter's maturity: the occasion of a birth or marriage, for example, or the inheritance of a title. ${ }^{\text {vii }}$ The Trioson portraits were extremely unusual—perhaps even unique, Sylvain Bellenger has claimed — in their repeated depiction of a young child in which individual portraits are separated by relatively brief intervals. ${ }^{\text {ix }}$ The acute temporal compression of the series would have been well suited to Girodet's experience of historical events in the final years of the eighteenth century. As an ambitious and promising pupil of the eminent neoclassical painter Jacques-Louis David, Girodet had left France in 1790 on a Rome Prize. He spent several years in Italy studying Renaissance and Greco-Roman art, during which he remained in close contact with his mentor Benoit-François Trioson. Girodet remained deeply invested in Revolutionary events while abroad. He initially expressed enthusiastic support for its reforms, styling himself as a citoyen, voluntarily relinquishing (through Trioson) his aristocratic title, and even defending the Académie de France in Rome from a violent, anti-French mob in 1793. But the France to which Girodet returned in 1795 bore little resemblance to the country he had left. 
The monarchical, religious, and social structures with which he grew up had been completely dismantled and reconfigured, and the political ideals to which Girodet was once attracted seemed fatally comprised by the violent events of the Reign of Terror, a movement in which Girodet's teacher David had been actively involved. Once the foremost artist in Republican France, David had been imprisoned twice by the time Girodet arrived in Paris. David's precipitous rise and fall were characteristic of a political climate in which factional coalitions and legislative bodies were in near-constant realignment.

The compressed temporality of the Trioson portrait series was sympathetic, then, to the accelerated pace of political change that had characterized the preceding years. In taking quite a young child as their subject, the portraits intensified the temporal sequencing that characterizes serial portraiture, for Benoît-Agnès's appearance changed significantly between each painting. ${ }^{x}$ In the 1797 portrait, Benoît-Agnès, his round cheeks mottled with blush, is painted sitting in front of an illustrated bible, Figures de la Bible, whose stiff, cumbrous pages slacken against his outstretched forearm. The boy retains the casual attire and unshorn curls of childhood. In the subsequent portrait of 1800 , his face is slimmer and his nose more defined, but his compressed lips, deep-set eyes, and dimpled chin clearly indicate that this is the same boy. His cropped hair and skirted knee-length coat anticipate an approaching transition to the mature deportment of adolescence, but their voluminous and disorderly state attest to the boy's as-yet unbridled physicality. ${ }^{\mathrm{xi}}$ In the final portrait of 1803 , Benoit-Agnès is neatly attired as a young man, with shorn hair, an elongated face, and more deeply set eyes. He leans over a large globe and rests his hand confidently on a book, objects over which he has attained physical mastery. Such traits, which index the boy's maturation, come clearly into view when the series is considered as a whole. 
Seen individually, the paintings each capture a particular moment and developmental stage. But what is not and, indeed, cannot be captured in a single portrait is the dramatic process of physical and psychological transformation taking place. The larger narrative of growth and maturation that is so essential to the series is, at the same time, a narrative that can only be grasped when looking across or between individual paintings. In attributing such a "narrative" to this series I mean that the individual paintings are linked by the sequence of visible changes they depict: the boy learns, develops, and grows as the result of the passage of time. The paintings are linked, moreover, by the sequential order in which they are arranged within a series, their relative placement along a linear temporal continuum. Both the portrait series (as a collection of paintings) and its narrative content are predicated on some kind of linear temporality. It is likewise presumed that the temporalities governing each are completely synchronous- that the duration separating the making of one painting from the making of another is identical to the amount of time that has elapsed in the boy's life.

Intriguingly, the portrait series affirms temporal continuity through measured forms of pictorial discontinuity. The series turns on the careful distribution of sameness and differencethe recurrence of certain physical features to secure the identity of the subject and the alteration of other features to denote his maturation. That is, the paintings must be similar enough to enable the viewer to recognize Benoît-Agnès, to posit some kind of enduring psychic and physical personhood across the series. Yet they must also be dissimilar enough to mark the portraits as belonging to different moments and separate developmental stages in the boy's life. Thus, within a unifying narrative of growth, each painting takes on meaning through its similarities to and differences from others in the series. What undergirds the portrait series is a model of time that is cumulative, durational, and sequential, and within which a painting can be located through the 
play of resemblance and dissemblance, of continuity and discontinuity. Broadly speaking, Benoit-Agnès, in his youthfulness, amplifies the uniquely temporal nature of the portrait series as a genre. But the Trioson portraits go further, drawing together temporal durations that, in their sheer excess, build up or accumulate around their subject in unexpected ways.

\section{Natural Histories}

An individual viewer encountering one of the portraits of Benoit-Agnès at the annual Salon in Paris would not have known of its placement within a series, especially given the multiyear interval that separated the exhibition of the second portrait in 1800 and the third portrait in 1806. The portraits were never exhibited together during Girodet's lifetime. Yet viewers would have nonetheless encountered paintings that were exceptionally preoccupied with temporality. Each painting surrounds its sitter with objects that recall historical depths of many stripes, histories that might appear incongruously paired with such a youthful protagonist. The 1797 portrait, for example, portrays Benoît-Agnès alongside a subtle allusion to profound and contested temporal expanses that have, at least at first glance, little to do with the subject at hand.

In this first painting, Girodet adopted many of the conventions established by earlier child portraits, including the close framing of the sitter, the presence of a wooden table against a nondescript brown-hued backdrop, and a finely rendered selection of objects of play and study in the foreground. The painting resembles Jean-Baptiste Greuze's A Boy with a Lesson Book (fig. 6, 1757) and Joshua Reynolds's Boy Reading (1747) and falls within a much longer history of portraying young men with instructional texts. ${ }^{\text {xii }}$ Colourful playing cards and toys spill out of the boy's pocket and the open drawer in the foreground, the temptations of leisure. But BenoitAgnès has set them aside to attend to weightier matters. The orientation of the boy's body towards the book, with only his head turned towards the viewer, suggests an ongoing activity 
that has been briefly interrupted. One can imagine him studying the book's illustrations, having marked his favorites by folding the top corner of the opposite page, and looking up as someone enters the room or calls to him. There is subtle psycho-biographical content at work here too, for the boy's mother had died not long before this portrait was made. His eyebrows are raised and the skin under his full-lidded eyes is swollen and creased. The shades of vermillion that play across his cheeks may be lingering evidence of his tears rather than the vital flush of boyhood.

The first portrait's expression of personal development took as its signature prop the illustrated bible, whose weighty pages were slightly too large for the young Trioson to hold comfortably. The accessory signals Benoît-Agnès's childlike natural piety. Yet as an object of instruction the bible was surprisingly fraught. The portrait was painted during a relatively recent ebb of the Revolution's antagonism towards the Catholic Church following a highly politicized ban on public worship legislated in 1793 and revoked under the Convention in early 1795. xiii Beyond this more immediate context, though, the bible lay at the heart of a multi-decade dispute - of which Girodet was undoubtedly aware - concerning rival explanations about the formation of the earth. It was an object against which the eighteenth-century had posited a new and distinct model of time. The biblical account of Creation had been losing scientific credibility in Enlightenment circles since the mid- to late seventeenth century. ${ }^{\text {xiv }}$ By the middle of the eighteenth century, alternative theories were published that attributed much more profound temporal depths to the natural world. The most prominent of these was written by Georges-Louis Leclerc, Comte de Buffon - a friend of Benoît-François Trioson. Benoît-François was a medical doctor who had been firmly established in the scientific communities of the ancien régime, counting among his titles Médecin ordinaire du Roi et ses Camps et Armées; Médecin de quartier Monseigneur Comte d'Artois et de SAS Monseigneur le Duc d'Orléans, premier Prince 
du Sang; and Médecin de Mesdames, tantes du Roi. The doctor's royal patronage and his embeddedness within a network of highly-respected scientists, intellectuals, and politicians were among the reasons Girodet's parents had initially asked their trusted friend to oversee the education of their youngest son. ${ }^{\mathrm{xv}}$ Like many successful men of science in the eighteenth century, Benoît-François was a gentleman-doctor, a man of privilege whose professional pursuits were seamlessly integrated into his personal and political activities at court. As Girodet grew, his mentor guided his tastes, filled his library, and introduced him to the system of Enlightenment sociability that had been crucial to the doctor's own success. Trioson ensured that Girodet had specialized knowledge about natural history and medicine in addition to a more standard, broad intellectual grounding in classical and contemporary literature, philosophy, and history. Young Benoît-Agnès's education would have been directed in much the same way.

Benoît-François was greatly interested in the work of Buffon, which was a topic of routine discussion at the salons he frequented in the 1770s and 1780s. Buffon's enormously influential mid-century, multi-volume Histoire naturelle (Natural History), which both Girodet and his mentor owned copies of, had, in a supplement titled Les Époques de la nature (The Epochs of Nature), boldly upended earlier estimates about the Earth's history. ${ }^{\mathrm{xvi}}$ Whereas most seventeenth-century naturalists held that the world was a few thousand years old, a view that accorded with the Old Testament, Buffon disputed the biblical account of Creation. He proposed that Earth was approximately 75,000 years old, an age roughly ten times greater than was previously believed. By the eighteenth century's end, the flourishing study of geology in western Europe permanently altered mainstream scientific accounts of the natural world, which had come to see the present state of the Earth as the cumulative result of events occurring over several millennia. ${ }^{x v i i}$ 
The framework of geological time, incompatible with biblical time, treated the world as the result of multiple (and perhaps even ongoing) processes rather than as a fixed and homogeneous entity. It was not merely a matter of contradicting Catholic doctrine; it necessitated a significant reorientation in how man understood his entire environment. This trend - namely, to conceive of the natural world as a deeply historical object—was most emphatically expressed in the 1780s by James Hutton, who proposed the concept of "deep time," a way of accounting for geologic events that could not be accommodated within the scale of human history. ${ }^{\text {xviii }}$ Deep time was an especially provocative and resonant concept because it presupposed a natural world whose life span was so vast as to require an entirely new way of measuring time. ${ }^{\mathrm{xix}}$ So when painting young Benoit-Agnès for the first time, Girodet paired him with items that, on the surface, allude to the boy's imminent transition from the world of play to the world of study and signal his youthful piety. But the bible in front of Benoît-Agnès had a subterranean temporality; for, its historical authority had been very publicly challenged and then discarded. In the process, nature itself had been endowed with vast and unprecedented historicity. When Benoît-Agnès was old enough to read his father's books, he would have learned that a new account had supplanted the biblical explanation of the earth's formation - and in particular, he would have learned that his world was much, much older than previously claimed. Indeed, much older than any calendar or almanac could quantify.

\section{Accumulations}

If this reference to the study of nature remained latent in the 1797 portrait, it surfaced more decidedly in the 1800 portrait that followed. Here, multiple accessories of Benoit-Agnès's education, connected by the tangled path of a single thread, are scattered in the foreground: a violin, a Latin grammar book, a charcoal pencil, a beetle, a walnut shell (half of which has 
replaced the violin's bridge), a partially eaten loaf of bread, paper covered with drawings, and a single butterfly pinned to the upholstery of the chair on which they have been assembled. This selection of objects belonged to an iconographic vocabulary with which Girodet was quite familiar and which he had recently deployed, with devastating precision, in his 1799 portrait Mme Lange as Danae. Such objects have featured prominently in art historical accounts of the portrait. The sheer accumulation of these items - "freighted," Tom Crow writes, "with an overlay of metaphysical conceits" - has invited a number of iconographic readings. ${ }^{\mathrm{xx}}$ The butterfly, for example, had specific resonances to a turn-of-the-century audience, particularly as an ancient symbol of the soul. ${ }^{\mathrm{xxi}}$ Or perhaps, as George Levitine argued, the creature's unhappy fate, pinned to a chair, resembles the young boy's reluctant confinement to his studies. ${ }^{\text {xxii }}$ In this body of scholarly literature, the emphasis has fallen, overwhelmingly, on how such objects reveal the portrait's psychobiographical content. ${ }^{x i i i}$

But the butterfly was also a practical object, the kind of specimen that Benoît-Agnès would have examined as part of his education in "natural history," the scientific study of the natural world (although not yet called "science"). ${ }^{\text {xiv }}$ The pursuit of natural history was a popular pastime among educated men of polite society. ${ }^{x x v}$ Triangulated by networks of commerce, politesse, and entertainment, this largely fell under the rubric of amateurism, a rather porous term that distinguished leisure study from dedicated academic scholarship. ${ }^{\text {xxi }}$ Under the tutelage of his father Benoît-Agnès, like Girodet, would have been encouraged to study natural history with an unusual degree of seriousness and rigour. I would venture that, counterintuitive as it may seem, treating the butterfly as a specimen of natural history is ultimately more revealing of how the portrait frames selfhood than the iconographic and psychobiographic readings this object typically engenders in scholarship on the portrait. 
The butterfly qua specimen plays a more particular emblematic role in the context of this portrait. It stands for a temporal structure of growth and maturation that is so central to the enterprise of serial child portraiture. After all, it was the insect's dramatic transformation from cocoon-like chrysalis to jewel-toned butterfly that made it a privileged object of study for eighteenth-century naturalists. The entomological diagrams that Benoit-Agnès would have studied in Buffon's Histoire Naturelle or Denis Diderot's Encylopédie (fig. 7) illustrate the insect's transformation across a series of developmental stages. The butterfly's mature stagewhat entomologists call the imago - is both linked to and distinct from that which precedes it. But whereas the diagram condenses these developmental stages into a single image, the portrait series works through them in separate but sequentially ordered images. With Benoît-Agnès's death in 1804 , that process was abruptly halted. Like the specimen that never matures, the boy is an image without an imago. Benoît-Agnès and his preserved butterfly have been subjected to analogous procedures that temporally arrest each at a specific stage in their development. Both are preserved; both have become specimens.

The cyclical temporality or life cycle of the butterfly is contrasted in the 1800 portrait with a much more practical material history: the butterfly, like the Egyptian scarab beetle in the painting's foreground, would have been part of an entire collection of natural specimens. Indeed, the butterfly is pinned against the upholstery of the chair in the foreground as if displayed under glass as part of a naturalist's collection. Eighteenth-century Parisians of the haute monde assembled collections curieuses (collections of curiosities), private collections that facilitated the amateur study of nature and history and simultaneously attested to the taste and affluence of the collector. ${ }^{\text {xvii }}$ Through the collection and its ordered display, its curator could display his erudition, his aesthetic principles, and, to an extent, his larger worldview. Collecting, then, was a 
point of contact between practices by which one shapes one's identity and practices that are cumulative in a literal and material sense — that is, in which something is realized through the accrual of objects over time. Extravagant collections curieuses often included porcelain, lacquer work, prints, drawings, weapons, foreign clothing, and other rare objects aggregated from both historically and geographically remote sources. Tools and specimens related to the study of natural history were also commonly featured. ${ }^{\text {xxviii }}$ On display in their homes, these rare and precious objects were part of an elite economy of collecting.

The cabinet d'histoire naturelle (cabinet of natural history), unlike the collection curieuse, was a more specialized scientific collection that could include shells, dried plants, preserved insects and animals, minerals, and various specimens related to the fields of botany, geology, entomology, zoology, and minerology—subjects of unprecedented popularity among the European gentry. The closely related cabinet de physique focused on fields like physics, chemistry, and astronomy, and included telescopes, astronomical instruments, globes, and various tools for conducting experiments. Both Benoît-François and Girodet participated in this culture of collecting. The elderly doctor's valuable cabinet de physique (cabinet of "physics") and cabinet d'histoire naturelle, which Girodet consulted when planning some of his paintings, were included in the 1788 marriage contract between Benoit-François and Marie-Jeanne Mallet. ${ }^{\text {xix }}$ When painting the sole child to result from this marriage in 1800, Girodet surrounded him with objects that anticipated his future participation in this culture of collecting. In doing so, the artist also noted, with a touch of melancholy, the analogous relationship between the boy and the specimens his father collected. Piled up on the foreground of the portrait, the Egyptian scarab beetle and the preserved butterfly served as accessories to the boy's education, but they are also 
the rich sediment of natural histories, visible particles deposited over time that bear witness to the longer processes that brought them thither.

\section{The Student of History}

In the final portrait of 1803 , the boy's education is portrayed in more formal and conventional terms. Benoît-Agnès had advanced to the study of ancient history. He touches Commentaires de César sur la guerre civile (Commentaries on the Civil War) with one hand and uses the other to pinpoint, with the assistance of his father, the sites of African battles recounted in the text. Additional red volumes line the shelf in the left background, atop which sits a bronze bust of the Greek physician Hippocrates. Properly considered, the 1803 portrait is a double portrait of father and son, and was exhibited as such in the Salon of 1806. Their relative placement within the composition underscores the historical knowledge being passed from one to the other. On the left, the bust of Hippocrates (an ancient physician greatly admired by doctor Trioson) casts a dark, orb-like shadow that falls just behind the head of Benoît-François. Here the minds of the two men meet, a nod to their shared intellectual lineage. Benoit-François is a compositional midway point between the bronze bust and the adolescent boy. The former's face is frontal, the latter's is in full profile, and the aging doctor, mediating past and future through his compositional placement but also through the act of instructing his son, turns towards the boy in three-quarter profile. Their hands mirror and echo each other. On the left two outstretched fingers reach towards each other over a point on the globe. On the right, two elegantly tapered hands rest, one on the globe and the other on the book, each with an index finger splayed, the middle fingers curled together, and the pinkie extended slightly to the right. These hands reinforce the physical resemblance of father and son, and may allude to Benoît-Agnès's anticipated career as a physician, a profession that, for all its intellectual rigour, also demanded 
physical intervention and manual dexterity. They also affirm the transmission and reception of knowledge taking place, under the sign of Hippocrates, between the boy and his father.

Scenes of study and instructive recreation were typical of eighteenth-century child portraits. They offered a means of capturing activities that were unique to childhood while also attributing desirable traits such as diligence and erudition to the as-yet unformed adult. More than this, though, they engaged with one of the most topical and pervasive philosophical questions of the day, namely education. This concerned both perfecting the practical course of a child's instruction and uncovering the more abstract process of how a child learns, how he cognitively grasps, retains, and orders information about the world. The enormously influential sensationalist philosopher Étienne Bonnot, Abbé de Condillac weighed in on both, publishing an Essai sur l'origine des connaissances humaines, or Essay on the Origins of Human Knowledge, in 1746 and a practical treatise on education Cours d'études pour l'instruction du prince de Parme, Course of Studies for the Instruction of the Prince of Parma, from 1767-1773. Girodet may or may not have read the latter, but he certainly owned a copy of Condillac's Essay on the Origins of Human Knowledge, as did Benoît-François. ${ }^{\mathrm{xxx}}$ He was also a close friend of the physiologist Pierre-Jean-Georges Cabanis, one of the leading proponents of Condillac's sensationalism in the 1790 s. Although Condillac's contemporary and friend Jean-Jacques Rousseau has been taken as the more obvious point of reference for Girodet's portraits of BenoîtAgnès, I propose that Concillac's sensationalist philosophy was an equally crucial part of the intellectual framework within which they were produced. ${ }^{\text {xxxi }}$

Sensationalist philosophy was far from arcane; as Jan Goldstein has argued, it was a widespread philosophical paradigm that provided "ordinary educated people in late eighteenthcentury France [a] general interpretive frame" for approaching the world. ${ }^{\text {xxxii }}$ Condillac's 
philosophy popularized a French variant of John Locke's epistemology; as such it rejected the category of innate ideas of Cartesian rationalism and instead foregrounded direct sensory engagement as the ultimate source of all human knowledge. ${ }^{\text {xxxiii }}$ Sensationalist philosophy encouraged the individual to explore the world through the senses - precisely the same attitude that motivated the study of natural history among the middle classes in the late eighteenth century. Empirically-grounded popular sciences and sense-based knowledge systems were mutually reliant and mutually affirming: the study of the natural world was instrumental to an individual's cognitive development. ${ }^{\text {xxiv }}$ Condillac famously imagined, in his 1754 Traité des sensations (Treatise on Sensations), an inert statue that is endowed with human senses, first one at a time and then in various combinations. His objective was to consider the kind of information each sense provides man, and therefore to analyse how the basic building blocks of sensory experience can ultimately produce complex knowledge about the world. From this thought experiment, Condillac concluded that learning is a slow and processual experience. ${ }^{\mathrm{xxxv}}$ Sensory input has to be received, stored, compared, and evaluated before it can be placed within a rational intellectual architecture. Thus for Condillac, all knowledge acquisition, rooted in sensory experience, is a gradual process that builds on itself over time.

As a result, Condillac's sensationalism was as much a philosophical project as it was a historical one. Or rather, his work pointed to the implicitly historical procedures of philosophical thought within an empirical framework: because, for Condillac, sensory experience is given as the ultimate origin of all knowledge, any meta-analysis of human knowledge necessarily comes after this. In the words of Jacques Derrida, Condillac's philosophy “is always late with respect to an operation of cognition." $x x x v i$ Because he is interested in processes of "becoming" and subscribes to a teleological enlightenment model of "progress," Condillac paid close attention to 
"the conditions of the historical possibility of his undertaking." Derrida continues, "this historical reflection never lets itself be separated from the undertaking itself; it analyses some particular conditions and situations but only in order to have posited first the general law of historicity. If philosophy $[\ldots]$ is essentially historical, that is because it always comes after the practice of cognition." "xxxvii Condillac was one of many enlightenment thinkers who described his philosophical project as an inquiry into the "origins" of human knowledge and whose intellectual framework was shaped by a belief in human progress. But Derrida reminds us that there was implicit temporal sequence at work here, too, in which the activity of the philosopher was perpetually looking back in time to the irreducible primacy of sensory experience.

Rousseau shared Condillac's interest in learning as something that develops over time and likewise his conviction that man relies a great deal on his material environment for the building blocks of knowledge. But Rousseau attributed more volition and intrinsic rationality to this process. His 1762 pedagogical treatise Émile (a copy of which Girodet owned) emphasized the natural innocence and vitality of children and argued that they should be protected from the corrupting influences of society. ${ }^{\text {xxviii }}$ In place of repressive and hierarchical forms of conventional education, Rousseau proposed a pedagogical system that would instead encourage the child's organic acquisition of knowledge and moral principles from the natural world around him. His hypothetical pupil Émile was trained to use his sensory faculties to actively evaluate, analyse, and compare the material structures of the natural world in lieu of - or, in the case of more moderate variations, as an important counterweight to - the passive reception of textual authority.

Girodet's 1803 portrait — the only one of the series to show Benoit-Agnès actively learning - is sympathetic to the principles held in common by Condillac and Rousseau. The 
boy's acquisition of knowledge is stimulated by his visual and tactile interaction with his surroundings, which is supported by (but not subordinate to) the book he touches with his left hand. His mastery of the book's contents is implied by the confident, familiar way he rests his weight on it and the tendril of fabric, presumably a page marker, that emerges from its shaded interior. Benoît-Agnès's attention is instead directed towards the globe, a materially imposing object that he can see and touch, and in doing so activate or reinforce the content of the text. In this regard he is pointedly unlike the young protagonist of Greuze's A Boy with a Lesson Book (fig. 6), whose intense, fixed gaze and bent head indicate the boy's efforts to memorize the text. Girodet's portrait, in contrast, reflects a significant shift in late eighteenth-century pedagogical theories, which privileged sensory engagement over rote memorization. However, memory itself remained a critical tool in both contexts. The 1803 portrait implies that Benoît-Agnès is recalling the contents of the book to his mind while pointing to relevant places on the globe. This scene of instruction conforms to contemporaneous ideas about learning as something that accumulates over time. Although Locke, Rousseau, and Condillac had different ideas about the specific operations of memory, all three agreed that memory is a constitutive feature of learning and cognition—and, indeed, of selfhood. ${ }^{\mathrm{xxxix}}$

\section{The Self in Formation}

Part of what makes the Trioson portrait series so deeply enmeshed in the question of selfhood is that in the late eighteenth century childhood, more broadly conceived, was being invoked as a constitutive stage through or against which adult identity could be articulated. For Condillac, the distinction between childhood and adulthood was not an ontological one. Because Condillac's radical sensationalist doctrine attributed the faculties of reason, memory, judgment, and imagination to sensory experience, these faculties are seen to be gradually acquired and 
refined by the same processual mechanism that activates the very first thoughts of his statue-man or a human child. He summarized the process as follows: "The germ of the art of thinking is in our sensations: needs arise, their development is swift and thought is formed almost at the moment they begin: because to feel needs is to feel desires, and as soon as we have desires we are gifted with attention and memory: we compare, we judge, we reason." ${ }^{\text {"xl }}$ Although the event of human thought happens soon after sensory experience (note the terms "swiftly," "almost at the moment," and "soon") it is nonetheless something that takes time. The adult, advanced both in his knowledge of the world and in his mental faculties, is located within the same developmental continuum as the child. The implication here is that adult cognition is not fundamentally different from that of the child, it is merely further along in a process that is durational and unceasing.

Condillac was going against the grain of mid-eighteenth-century thought in this regard. The Trioson portrait series was executed in a period often associated with the 'invention' of childhood, or at least its consolidation into what remains, more or less, our contemporary sense of the term. In the eighteenth century the child was an object of unprecedented interest both as an important stage in human development and as an arena in which the serious task of cultivating one's adult identity was said to begin. This becomes especially apparent in Jean-Siméon Chardin's paintings from the 1730s and 1740s, which show individual children diligently engaging in instructive recreation. Chardin's paintings mark the decline of a late seventeenthcentury conception of the child as naturally barbaric and unintelligent. ${ }^{\mathrm{xli}}$ Unlike many genre scenes of the seventeenth century, the young protagonists of Chardin's paintings from the 1730s and 1740s couple scenes of youthful play with the accessories of imminent adulthood. The figures in House of Cards (fig.6) and Boy with a Top are elegantly attired in buttoned waistcoats 
and overcoats, standing upright at tables with their curled coiffures pulled back by thick black ribbon. Even the relatively unkempt figure in Soap Bubbles has fully buttoned his careworn coat and tied up his hair. Such details propose a contiguity between present recreation and future refinement: although Chardin paid considerable attention to the unique comportment and behaviour of youth, the children in his paintings often exhibit the restraint and thoughtful attentiveness attributed to adults. Yet he continued to borrow from the moralising subtext of Dutch genre scenes, for his figures are surrounded by objects of precarity and evanescence, allusions perhaps to the fleeting nature of childhood itself.

Greuze's paintings from the 1750s, in contrast, indicate greater interest in the affective and physical particularities of early childhood. ${ }^{x l i i}$ His young protagonists protectively clutch their toys, fall asleep on top of neglected lessons, and casually slouch over disproportionately large tables. Their relative inactivity aligns them more closely with the portraits Girodet would paint in 1797 and 1800: whereas Chardin's children are industrious in their leisure activities, those painted by Greuze appear suspended in cognitive states that are inaccessible to the viewer- they are lost in concentration or staring dreamily at their instruments. Their loose, unconstraining attire and casual hairstyles also indicate a willingness to acknowledge the distinct needs and limitations of the child's body, a body that was, Anne Higonnet writes, "defined by its difference from adult bodies." ${ }^{\text {"liii }}$ Here again difference becomes a key strategy by which identity is located within a temporal continuum. In this context, the child and the adult are understood to be part of a single psychic and physical self, yet their relationship hinges on dissimilarity as much as it does on similarity.

Epitomized by the writings of Rousseau and others, the late eighteenth century has been associated with the rise of the "romantic child," a widely-held conception of the child as an 
intrinsically innocent being who is seen to be constitutively different from adults in physical, psychological, and experiential terms. ${ }^{\text {xliv }}$ The term itself should be treated with caution, for it overlooks some of the dynamic historical complexities how childhood was conceptualised. Yet it remains useful as an evocation the period's intensified interest in the moral, affective, experiential, and intellectual particularities of youth. Intriguingly, it is the very difference between the child and the adult that made childhood central to ideas about selfhood, for the child's impressionability and innocence were seen as fertile ground on which a more enlightened adult could be built. Correspondingly, both philosophers and politicians alike turned their attention to childhood development, whose value resided in large part in the potential future adult being formed. Nor was this relationship purely conceptual. Shifting philosophical discourses about childhood coincided with broader educational reforms before, during, and after the Revolution that sought to transform societal structures through the instruction of its youngest members. ${ }^{x l v}$ For example, Directory Idéologues, inspired by Condillac's philosophy, insisted that natural history play a key role in the curriculum of the public Écoles centrales, which were established in 1795 and remained in place until 1802. ${ }^{\text {xlvi }}$ Although such reforms were undertaken for much more practical purposes they acted on the increasingly pervasive belief that the psychological make-up of the adult is largely determined by one's childhood. In 1794 at the urging of Maximilian Robespierre, David mobilized this notion of childhood in his unfinished portrait of The Death of Young Bara, a direct appeal to the "boy-martyr" as an emblem of heroic republican innocence and purity. ${ }^{x l v i i}$ This emblematic use of childhood, though, depicted the adolescent with little indication that young Bara was endowed with distinctly childlike physical and psychological features. His idealized nude figure is located in an indeterminate space and suspended in a state of youthful perfection. 
In pointed contrast to David's Bara, Girodet's series places unique emphasis on the psychological particularities of childhood and especially its unique brand of loneliness and desultory melancholy found in the first and second portraits. Despite his small stature, BenoitAgnès fills the frame of each painting. Minutes details of his dress are carefully delineated as are his accessories, which are often endowed with weighty iconographic significance. Girodet once argued that the 1797 portrait belonged to le genre historique, yet another indication that these paintings were much more than just personal portraits. ${ }^{\text {xviii }}$ They were—or, at least, were as much - portraits about what it means to be a person. And in taking the child as their subject, they reflected the growing significance childhood was being given in late eighteenth-century thought as a platform through which adult selfhood is formed.

\section{Revolutionary Times}

The processual frameworks that I have identified in the portrait series align the process of becoming a self with varied, heterogeneous temporal accumulations. But what kind of self might be in formation? In recent decades there has been growing interest in more precisely defining the model of selfhood that was invented or consolidated in late eighteenth-century Europe. .lix $^{\text {. }}$ Certainly, questions about how individual psychic identity could be squared with collective political identity have preoccupied art historians of the Revolutionary era for quite some time. ${ }^{1}$ One of the most influential historical accounts in recent years was put forward by Jan Goldstein in The Post-Revolutionary Self. Goldstein argues that Condillac's sensationalism produced a French model of selfhood that was porous, passive, and contingent, in constant flux with the material world. According to Goldstein, this model was deemed too weak to stabilize a postRevolutionary world order and was therefore abandoned in favour of the robust, volitional, $a$ priori self posited by Victor Cousin. Dror Wahrman, in The Making of the Modern Self, looks to 
eighteenth-century England. Analysing a more diverse body of cultural activity, he argues a different but related point: that the malleability and collectivity of an old regime of selfhood gave way to model of identity as "personal, interiorized, essential, even innate." Hi However, the Trioson portrait series, though very much in dialogue with the philosophical context explored by Goldstein, does not offer a coherent paradigm of selfhood that affirms or contests either of these arguments. Instead, one could read the series as transitional, as documenting a process of coming-into-being as a self that is neither radically contingent per Condillac, nor totally fixed and essentialized. But the paintings offer little in the way of resolution. In the Trioson portraits selfhood is durational and cumulative but not in the sense that it is radically contingent; likewise, selfhood is consistent across the series but not in the sense that it is a priori. Here the "romantic child" has something particularly productive to offer-at least insofar as it evokes a profound reconfiguration in how childhood was conceptualised: Carolyn Steedman, in Strange Dislocations, argues that the idea of an interiorised self, as it was articulated in the late eighteenth century, associated identity with a kind of psychic history, as the aggregate of one's past experiences. ${ }^{\text {lii }}$ Accordingly, childhood came to be understood as a foundational era in that history, a repository for one's psychic past and the basis upon which one's present selfunderstanding could be built.

Whatever the self was for Girodet, in these works it emerges as an entity surrounded by and articulated in dialogue with densely layered durational processes, temporal expenses, and sequential narratives. It was a self whose operations were, on some level, represented as historical. In its sheer preoccupation with history, the Trioson portrait series might therefore appear to exemplify Michel Foucault's claim that, "for eighteenth-century thought, chronological sequences are merely a property and a more or less blurred expression of the order of beings; 
from the nineteenth century, they express, in a more or less direct fashion, and even in their interruptions, the profoundly historical mode of being of things and men."liii Of course, Foucault's periodization tends to deny eighteenth-century thought its well-documented historicity. ${ }^{\text {liv }}$ Yet it remains true that history came to play a uniquely important role in operations of both knowledge production and self-understanding in the early decades of the nineteenth century. This remained true despite—or, rather, precisely because of — the lack of conceptual stability or homogeneity to the category of the "historical" itself. The philosophical and literary procedures by which one narrated the past, participated in the present, and anticipated the future were thrown into disarray by the events of 1789 to 1815 , even if we treat with caution Reinhart Koselleck's famous assertion that the French Revolution marked an irreversible rupture in the European conception of historical time. ${ }^{\text {lv }}$ The hinge of the nineteenth century witnessed the violence and trauma of The Terror, its disavowal under the Directory, Napoleon's consolidation of power under the Consulate, and finally the declaration of the First French Empire, all of which was followed by over a decade of European warfare. The Trioson portrait series was executed during a period that underwent significant reorganizations of power and, accordingly, dramatic changes in how the recent historical past was being framed. It coincided with the production of an unprecedented volume of texts and images in England and France that endeavoured to pin down some kind of stable history and in doing so mediate one's relationship to the recent past. ${ }^{\text {lvi }}$ New pictorial strategies were likewise mobilised in the late eighteenth and early nineteenth centuries to invent, access, or revise the historical past. ${ }^{\text {lvii }}$

Ultimately, the Trioson portrait series is hard to locate within existing metanarratives of selfhood and history. Instead, it calls for a more heterogeneous and cumulative account of both. The difficulty of these paintings, as art historical objects, resides precisely in their inability to sit 
comfortably within such narratives, and, simultaneously, their reluctance to offer a coherent critique of them. The Trioson portraits offer a much more variable and capacious world view. In Girodet's portraits of Benoit-Agnès we encounter not a monolithic nor consistent model of self or history but rather a complex matrix of cumulative temporalities, some of which are experiential and psychic, others quotidian and material, and others still so vast that they lie beyond conventional understandings of historical time. They gather around Benoit-Agnès like sediment, piling up unevenly across the series. In a moment during which conceptions of both the self and history were in flux, Girodet produced a portrait series redolent with lumpy, heterogeneous, processual durations that trailed off abruptly, that dispersed into thinning wisps of charcoal in Girodet's final, post-mortem portrait (fig. 1). Perhaps Girodet was, after all, particularly alive to the variability and cumulative duration of being a person in the world. A few years after the untimely death of Benoit-Agnès, Girodet's own identity was continuing to acquire new dimensions. The artist was legally adopted by Benoît-François Trioson and thereafter was known as Girodet-Trioson.

This paper grew out of research undertaken for a conference on "Visualising Learning" at the University of St Andrews in May 2017; I would like to thank the participants for their constructive feedback and Linda Goddard for co-convening the event. Particular thanks are also due to Natalie Adamson, Emma Barker, Anne Higonnet, Sam Rose, Rachel Silveri, and Aaron Wile for reading drafts of this article, as well as to two the anonymous reviewers for their insightful comments.

${ }^{\text {i } G i r o d e t ~ 1767-1824, ~ e d . ~ S y l v a i n ~ B e l l e n g e r ~(P a r i s: ~ G a l l i m a r d, ~ 2005), ~ 375-6 . ~ T h e ~ r o l e ~ o f ~}$ "childhood" as a historical concept has also been discussed with reference to these works in George Levitine, Girodet-Trioson: An Iconographical Study (New York: Garland Publishing, 1978); Sidonie Lemeux-Fraitot, "Ut Poeta Pictor: Les champs culturels et littéraires d'AnneLouis Girodet-Trioson" (PhD diss., Université de Paris I-Panthéon Sorbonne, 2003); Robert Rosenblum, The Romantic Child (London: Thames \& Hudson, 1988). 
${ }^{i i}$ For example: Emma Barker, "Imagining Childhood in Eighteenth-Century France: Greuze's Little Girl with a Dog," The Art Bulletin 91, no. 4 (2009), pp. 426-445; Carol Duncan, "Happy Mothers and Other New Ideas in French Art," The Art Bulletin 55 no. 4 (1973), pp. 570-583; Dorothy Johnson, "Picturing Pedagogy: Education and the Child in the Paintings of Chardin," Eighteenth-Century Studies 24, no. 1(1990), pp. 47-68.

iii It is often assumed that the "genre historique" did not emerge until the 1830s. However, as Susan Siegfried has argued, its formation actually began around the turn of the nineteenth century. Susan Siegfried, "Naked History: The Rhetoric of Military Painting in Postrevolutionary France," The Art Builletin 75 no. 2 (Jun., 1993), pp. 250.

iv This has been most thoroughly addressed in Amy Freund, Portraiture and Politics in Revolutionary France (Univ. Park: Penn State Univ. Press, 2014). Girodet's portraits have been discussed in some detail by Tom Crow, Emulation: Making Artists for Revolutionary France (New Haven: Yale University Press, 1995) and Darcy Grigsby, Extremities: Painting Empire in Post-Revolutionary France (New Haven: Yale Univ. Press, 2002).

${ }^{v}$ Dorothy Johnson, "Engaging Identity: Portraits of Children in Late Eighteenth-Century European Art," in Anja Muller ed., Fashioning Childhood in the Eighteenth Century: Age and Identity (Aldershot, 2006), pp. 101-16. For the political aspects of familial portraiture see Freund, Portraiture and Politics in Revolutionary France, pp. 199-234. Most recently, Emma Barker has argued that changes to family portraiture coincide with and reflect "the transfer of political authority away from the monarch." Emma Barker, "No Picture more Charming': The Family Portrait in Eighteenth-Century France, Art History 40 no. 3 (Jun., 2017), pp. 526-553. vi In doing so, I look back to T.J. Clark's analysis of philosophies of the self and a self-portrait of Girodet's teacher, Jacques-Louis David. The Trioson portrait series, however, is constitutively different in its operations and its subject matter. T.J. Clark, "Gross David with the Swoln Cheek: An Essay on Self-Portraiture," Rediscovering History: Culture, Politics, and the Psyche, ed. M.S. Roth (Stanford: Stanford Univ. Press, 1994), pp. 243-307.

${ }^{v i i} M o i$ was briefly synonymous with and gradually replaced $\hat{a}$ me as the philosophical term for selfhood in the late eighteenth and early nineteenth centuries. Jan Goldstein, The PostRevolutionary Self: Politics and Psyche in France, 1780-1850 (Cambridge: Harvard Univ. Press, 2005), pp. 115-118.

viii Serial portraiture, as a practice, has ancient roots: in Greco-Roman antiquity, for example, rulers would have multiple versions of their likeness in circulation as a way to authenticate and disseminate their power. However, "serial portraiture" was not considered its own "genre" in the eighteenth century. Speaking of the Trioson portraits as a "series" is, I should note, a retroactive designation on my part rather than a category that would have been officially recognized as such in the context of eighteenth-century academic art. I also exclude serial self-portraiture from my discussion, which I consider a fundamentally different undertaking. For more on serial selfportraiture, see, for example: H. Perry Chapman, Rembrandt's Self-Portraits: A Study in Seventeenth-Century Identity (Princeton: Princeton Univ. Press, 1992).

ix Bellenger, Girodet 1767-1824, 375.

${ }^{\mathrm{x}}$ The temporal dynamic of eighteenth-century serial portraiture has been explored in the British context in Whitney Davis, "Serial Portraiture and the Death of Man in Late-Eighteenth-Century Britain." A Companion to British Art: 1600 to the Present. Eds. Dana Arnold and David Peters Corbett (Chichester: Wiley-Blackwell, 2013), pp. 502-531.

${ }^{x i}$ I thank Anne Higonnet for pointing out that Benoît-Agnès was wearing the newly fashionable pants and vest created for older boys, rather than the dress reserved for the very young. 
${ }^{x i i}$ For an overview of the cultural context of such portraits, see M.O. Greenby, The Child Reader 1700-1840 (Cambridge: Cambridge Univ. Press, 2011).

xiii A good summary of this history can be found in Nigel Aston, Religion and Revolution in France, 1780-1804 (Washington D.C.: Catholic Univ. Press, 2000).

xiv See also: Gabriel Gohau, A History of Geology, translated by Albert Carozzi and Margeurite Carozzi (New Brunswick: Rutgers Univ. Press, 1990).

xv This relationship is discussed in detail in Sidonie Lemeux-Fraitot, "Le docteur Trioson," in "Ut Poeta Pictor."

xvi Lemeux-Fraitot, "Ut Poeta Pictor", appendix. no. 384.

${ }^{\text {xvii }}$ For a good summary of this, see Charlotte Klonk, "Science, Art, and the Representation of the Natural World," in Cambridge History of Science: Vo. 4, The Eighteenth Century (Cambridge: Cambridge Univ Press), pp. 584-617.

xviii Gabriel Gohau, A History of Geology, translated by Albert Carozzi and Margeurite Carozzi (New Brunswick: Rutgers Univ Press, 1990).

${ }^{x i x}$ It should be noted here that Hutton's theories did not gain much traction until after 1802, and were not particularly influential until the 1830s. Paolo Rossi explored the relationship between Enlightenment natural history and philosophy in Rossi, The Dark Abyss of Time (Chicago: Univ. of Chicago Press, 1984).

xx Crow, 307.

xxi Encyclopédie, ou dictionnaire raisonné des sciences, des arts et des métiers, vol. XI, ed. Denis Diderot (Paris: André le Breton, Michel-Antoine David, Laurent Durant, Antoine-Claude Briasson, 1765), 876.

xxii Levitine, 329.

xxiii For Crow, "the theme is empathy with self-indulgent immaturity. He depicts the boy in an isolated, dreamy state of passive rebellion against the responsibilities embodied in his Rudiments of Latin Grammar, the leaves of which fall negligently from his hand." Emulation, 247.

xxiv The use of the term "science" here is anachronistic. Steve Shapin points out that "science" historically described the broader theoretical and academic pursuit of knowledge, rather than the empirical study of natural phenomena. In the eighteenth century it went by the terms "natural history" and "natural philosophy." Steve Shapin, The Scientific Revolution (Chicago: Univ. of Chicago Press, 1996). Also see David Cahan, From Natural Philosophy to the Sciences (Chicago: Univ. of Chicago Press, 2003).

${ }^{\mathrm{xxv}}$ Public science was as much a source of pleasurable recreation as it was an earnest academic activity. For more on this, see Anne Secord, "Botany on a Plate: Pleasure and the Power of Pictures in Promoting Early Nineteenth-Century Scientific Knowledge" Isis 93 no. 1 (2002), 2845. Geoffrey Sutton, Science for a Polite Society: Gender, Culture, and the Demonstration of the Enlightenment (Oxford: Westview Press, 1995).

${ }^{x x v i}$ Aileen Fyfe and Bernard Lightman, eds. Science in the Marketplace: Nineteenth-century Sites and Experiences (Chicago: Univ. of Chicago Press, 2007). Michael R. Lynn, Popular Science and Public Opinion in Eighteenth-Century France (New York: Manchester Univ. Press, 2006). A valuable account of amateurism can be found in Sarah Easterby-Smith, "Selling Beautiful Knowledge: Amateurship, Botany, and the Market-Place in Late Eighteenth-Century France," Journal for Eighteenth-Century Studies 36, no. 4 (2013), 531-43.

xxvii Bettina Dietz and Thomas Nutz, "Collections Curieuses: The Aesthetics of Curiosity and Elite Lifestyle in Eighteenth-Century Paris," Eighteenth-Century Life 29 no. 3 (2005), pp. 44-75. 
xxvii On the relationship between antiquarianism and natural history, see Noah Heringman, Sciences of Antiquity: Romantic Antiquarianism, Natural History, and Knowledge Work (New York: Oxford Univ. Press, 2013).

xxix Girodet to Benoît-François Trioson, 16 June 1795. "Biochronologie," Girodet 1767-1824, ed. Sylvain Bellenger (Paris: Gallimard, 2005), 384.

${ }^{x x x}$ By 1789, Girodet owned both Condillac's Essai sur l'origine des connaissances humaines and La Logique ou les Premiers dévelopmments de l'art de penser. Sidonie Lemeux-Fraitot, "La Première bibliothèque de Girodet," Lemeux-Fraitot, appendix, n.p.

xxxi The relationship between Rousseau and the Trioson portrait series has been commented on in Levitine, 322-29 and in Bellenger, 375-6.

xxxii Goldstein, The Post-Revolutionary Self: Politics and Psyche in France, 175-1850

(Cambridge: Harvard Univ. Press, 2005), 8.

xxxiii For a good overview of sensationalism see Jessica Riskin, Science in the Age of Sensibility:

The Sentimental Empiricists of the French Enlightenment (Chicago: Univ. of Chicago Press, 2002); and, John O'Neal, The Authority of Experience: Sensationist Theory in the French Enlightenment (University Park: Pennsylvania State University Press, 1996).

xxxiv Although this was modified under the Napoleonic lycée system, the sensory study of the natural world was an important aspect of one's education under the Directory. See L. Pearce Williams, "Science, Education, and the French Revolution," Isis 44 no.4 (1953), pp. 311-330. Williams discusses its fate under Napoleon in a companion essay: "Science, Education and Napoleon I," Isis 47 no. 4 (1956), pp. 369-382.

xxxv In the words of John O'Neal, "the entire structure" of Condillac's analysis emphasizes "the extreme slowness of the process." O'Neal, Changing Minds: The Shifting Perceptions of Culture in Eighteenth-Century France (Newark: Univ. of Delaware Press, 2002$), 78$.

xxxvi Jacques Derrida, The Archaeology of the Frivolous: Reading Condillac, trans. John P. Leavey (Lincoln: Univ. of Nebraska Press, 1987), 40.

xxxvii Derrida, 40.

xxxviii Girodet possessed Emile, ou l'éducation as well as an edition of his complete works, which he probably inherited upon his father's death in the 1780s. Lemeux-Fraitot, "Ut Poeta Pictor," appendix, no. 249.

xxxix Jerrold Seigel, The Idea of the Self: Thought and Experience in Western Europe since the Seventeenth Century (Cambridge: Cambridge Univ. Press, 2005), 216.

${ }^{\mathrm{xl}}$ Étienne Bonnot de Condillac, Cours d'étude pour l'instruction du Prince de Parm (London: Chez les libraires François, 1776), vol. IV, 1.

xli Dorothy Johnson, "Picturing Pedagogy: Education and the Child in the Paintings of Chardin," Eighteenth-Century Studies 24, no. 1(1990), pp. 47-68.

xlii Emma Barker, "Imagining Childhood in Eighteenth-Century France: Greuze's Little Girl with a Dog."

xliii Anne Higonnet, Pictures of Innocence: The History and Crisis of Ideal Childhood (London: Thames and Hudson, 1998), 23

xliv For a thorough account, see Higonnet, Pictures of Innocence. Histories of childhood are not unanimous on this score. In 1960, Philippe Ariès influentially argued that the Middle Ages did not conceptualise childhood as a distinct developmental stage of human life. Ariès, Centuries of Childhood: A Social History of Family Life, trans. Robert Baldick (New York: Vintage, 1962). His thesis has been enthusiastically challenged in Nicholas Orme, Medieval Children (New Haven: Yale Univ. Press, 2003); and Barbara Hanawalt, 'The Child in the Middle Ages,' in 
Beyond the Century of the Child, eds. Willem Koops and Michael Zuckerman (Philadelphia: Univ. of Pennsylvania Press, 2012), pp. 21-42.

xlv A good account of this can be found in Margaret Archer and Michalina Vaughan, Social Conflict and Educational Change in England and France 1789-1848 (Cambridge: Cambridge Univ. Press, 1971).

xlvi They argued that the study of natural history would nurture the students' intrinsic rationality, self-directedness, and observational powers, and thus help them develop into ideal young citizens. Williams, "Science, Education and the French Revolution." xlvii See Crow, "A Child Shall Lead Them," in Emulation. xlviii Girodet to Neufchâteau, 16 September 1798. Girodet wrote to complain about the placement of two paintings in the Salon: "le portrait d'un nègre, représentant des Colonies, en méditation près du buste de Raynal, et celui d'un jene enfant regardant des figures dans un livre. Ces deux portraits sont presque en pied, et la manière dont ils sont traités les faits nécessairement rentrer dans le genre historique." Bruno Chenique, Biochronologie, 440.

xlix These can be seen as responses, to an extent, to Taylor's Sources of the Self: The Making of Modern Identity (Cambridge: Harvard Univ. Press, 1989).

${ }^{1}$ Most recent would be Freund, Portraiture and Politics. See also, T.J. Clark, "Gross David of the Swoln Cheek." For the psychosexual valences of this see Ewa Lajer-Burchart, Necklines: The Art of Jacques-Louis David After the Terror (New Haven: Yale Univ. Press, 1999); and Satish Padiyar, Chains: David, Canova, and the Fall of the Public Hero in Postrevolutionary France (University Park: Penn State Univ. Press, 2007).

${ }^{\text {li }}$ Dror Wahrman, The Making of the Modern Self, 276.

lii Carolyn Steedman, Strange Dislocations: Childhood and the Idea of Human Interiority, 17801930 (Cambridge: Harvard Univ. Press, 1994),

liii Michel Foucault, Order of Things (New York: Random House, 1970), 276.

${ }^{\text {liv }}$ For a thorough consideration of the rhetorical and conceptual strategies through which eighteenth-century historians managed their relationship to the past, see Mark Salber Philips, On Historical Distance (New Haven: Yale Univ. Press, 2013).

${ }^{1 v}$ Reinhart Koselleck, Futures Past: On the Semantics of Historical Time, trans. Keith Tribe (New York: Cambridge Univ. Press, 2004). The exceptionalism of this account should be approached with caution. It would be misleading to suggest that the eighteenth-century had a single, homogeneous conception of historical time. For a philosophical analysis see Harry Jansen, "In Search of New Times: Temporality in the Enlightenment and CounterEnlightenment," History and Theory 55 (2016): 66-90.

lvi Stephen Bann, Romanticism and the Rise of History (New York: Twayne Publishers, 1995).

lvii For a discussion of the contested authority of different visual media in this regard, see Richard Taws, "Telegraphic Images in Post-Revolutionary France," Art History 39 no. 2 (2016), pp. 400421. 